\title{
The New American Studies Research in the Era of the New Media: \\ Reading the Re-Writing of the Female Detective Protagonist of The Closer (TNT, 2005-2012) in The Closer Fanfiction ${ }^{1}$
}

\author{
Fitria Akhmerti Primasita \\ fitriaakhmerti@staff.uns.ac.id \\ English Department, Faculty of Cultural Sciences, \\ Sebelas Maret University \\ Surakarta, Central Java Province, Indonesia
}

\begin{abstract}
To overlook the proliferation of the new media in the twenty-first century in American Studies research negates the fact that American Studies today is American Studies in the era of the new media. This article aims to offer an alternative textual research on the representation of American television female detectives by analyzing how the representation of the female detective protagonist of the American television police procedural drama series The Closer (TNT, 2005-2012) is read by the fanfiction writers in The Closer Fanfiction in re-writing the female detective protagonist of The Closer TV series as the original text. The analysis shows that the fanfiction writers take similar dominant-hegemonic reading position of the representation of The Closer's female detective protagonist with the series' female viewers. Many of the writers explore the feminine sides as well as the feminine vulnerabilities of the female detective protagonist in their fiction works and the readers' comments show that the representation fits the expectation. The result affirms the maintaining of the ideologies of femininity in the life experience of American women.
\end{abstract}

Keywords: American Studies, New Media, fanfiction, American television female detective protagonist

\section{Introduction}

Writing A Concise Companion to American Studies six years after the ASA President Shelley Fisher Fishkin's Presidential Address to the "Internationalizing of American Studies" in 2004, Rowe observed the changing focus of research and teaching in American Studies scholarship. The new American Studies departed from the traditional emphasis on the internal diversity of the US to the comparative and transnational approach to the many different and constantly changing nations and communities that form the United States. [1] (p. 1) In Part III of the book titled 'The New American Studies', in identifying 'the concept of borders as an idea of consequence in American Studies scholarship', one of the contributors Opperman's observed and raised a

\footnotetext{
${ }^{1}$ This article is developed from the author's unpublished dissertation titled Representation of Female Detective in American Police Procedural Drama Series The Closer (TNT, 2005-2012). [2]
} 
concern that the World Wide Web and digital culture may have become a new border digitally dividing 'those who have begun to engage with new technologies in teaching or research (or both) from those who tend to ignore or avoid any involvement with new media that goes beyond the use of email and Google' (p. 334). Opperman [3] saw the need 'to change the status of new media from being something outside the field to something that advances the rigorous, problem-driven intellectual work that lies at the heart of the New American Studies project' (p. 347). Likewise, in his article 'Next Times: The Futures of American Studies Today', Rowe [4] himself acknowledged that there has been 'dramatic changes in [American Studies] teaching, research, and institutions wrought by new digital technology' (p. 267). While his main concern was on the problem of book publication, Rowe [4] did call for the need to experiment with what he called "new web genres online" in American Studies scholarship (p. 268).

To overlook the proliferation of the new media in the twenty-first century in American Studies research negates the fact that American Studies today is American Studies in the era of the new media. The transformation of the 'old media' to become 'new media' in the twenty-first century is ubiquitous. The production, distribution, and use of 'old media' experience changes on a regular basis to become 'new media' that are digital, interactive, hypertextual, virtual, networked, and simulated. [5] (p. 30) Prints, photographs, films and newspapers have now turned digital. The viewers of film and television or readers of literary works may become 'users' for having the ability to make use of their access to images and texts to directly intervene in and change the images and texts. The readers become 'users' as they choose the way they navigate hypertext poems or fiction through clicking the hyperlinks embedded in the words, phrases, or lines. More and more individuals around the world start to get used to roaming, out of personal need or necessity (especially during Covid-19 pandemic), ' $[\mathrm{t}]$ he World Wide Web, corporate intranets, Virtual Learning Environments, MPORPGs [Multi-Player Online Role Playing Games], 'persistent worlds', Social Network Sites, blog networks, online forums of all kinds, and humble email distribution lists [that] are ultimately connected in a vast, dense and (almost) global network (the Internet itself).' [5] (p. 31)

The new media proliferation should be taken as expanding data sources availability that requires more accommodating methodology of American Studies as a field of study. More varieties of sources of data are available in the study of American experience. This is so because, according to Beer, [6] '[m]illions of people on a global scale are engaging with [American] culture via these new media forms as they enchant, distract, entertain, reveal and occupy' (p. 1). In underlying the intersections of popular culture and new media, Beer [6] further asserts that '..., when thinking of new media, we should be thinking of the popular forms of culture that are a central part of their use and incorporation into everyday practice' (p. 1). As data sources availability expands, the interdisciplinary nature of the field of study's methodology needs to incorporate approaches and theories developed in emerging fields of study such as New Media Studies, Technology Studies, Cyberculture Studies, and also Fans Studies. According to Opperman, [3] it should be American Studies, not Media Studies, Cyberculture Studies, or other fields in the digital humanities, that will need to tackle inquiries about the impact of new cultural forms for American society by incorporating the new media to advance the teaching and research of the New American Studies (p. 347).

This article is written to fulfill the calling for incorporating the new media in the American Studies research by offering an alternative textual research on the 
representation of American television female detectives. In the twenty-first century, as a medium, television itself has entered what Spigel (2004) calls the 'phase that comes after TV' or what Lotz (2009) calls the 'post-network era' [7]. In this era, television and its cultural experience have been reshaped by the most encompassing technologydigitalization. [7] Researching a TV series that is not on air anymore is made easy by the availability of the series recording in Digital Video Disk (DVD) format. While such research can be considered utilizing television as new media, another textual research that connects television and the internet can be taken as an intriguing alternative.

The Closer is an American police procedural drama series that has a long lasting popularity. It was created as an original series to be on air on TNT cable television for seven years from 2005 to 2012. The police procedural is the new variant of the detective genre suitable for the complex and organized contemporary America. Police procedural drama series has recently been a trend on American television, but The Closer is distinct because the protagonist is a female detective who is very capable of doing the male job while still retaining her feminine look, demeanor, and utterance. The popularity of The Closer's female detective protagonist among her vast middle class female viewers shows that the viewers have taken a dominant-hegemonic reading position towards her representation on television. It is interesting to analyze how the representation of the female detective protagonist of the American television police procedural drama series The Closer (TNT, 2005-2012) is read by the fanfiction writers in The Closer Fanfiction in re-writing the female detective protagonist of The Closer $\mathrm{TV}$ series as the original text to know what reading position is taken by the writers. In this way, further understanding of the life experience of American women can be obtained.

\section{Discussion}

This main part starts with discussing how the American police procedural drama series The Closer (TNT, 2005-2012) as a genre associated with male viewers is produced to appeal female viewers by representing its female detective unlike the common female detective representation on American television. The discussion continues with how this unique representation is eventually given meaning by the fanfiction writers in The Closer Fanfiction.

\subsection{The Closer (TNT, 2005-2012) : Masculine Text, Feminine Response ${ }^{2}$}

From its early development, the heroes of the detective genre were exclusively, or almost exclusively, white heterosexual male. Even all Hard-boiled detectives are male [9] (p. 13). Cooper [10] suggests that the idea of the detective genre as the embodiment of the American male myth has been widely taken by scholars (p. 30). Mizejewski [11] points out that the detective genre is also taken as 'contemporary male epic' with the plot line that revolves around the notion of 'male sexuality as power, knowledge, entitlement; the female body as the site of seduction and death' (p. 15). In other words, detective genre is a masculine genre, and

${ }^{2}$ This phrase is originally used by Handley in her chapter "'Distressing Damsels:" Narrative Critique and Reinterpretation in Star Wars Fanfiction.' [8] The feminine response is the same for both Star Wars Fanfiction and The Closer Fanfiction as cultural texts, but what makes the response feminine is not similar. 
this means that the police procedural as the contemporary variant of the detective genre is also a masculine subgenre.

Female detectives as protagonists have been on American television since 1970s, but their representation has been stereotypical to reflect the dichotomy of male and female occupation. Policing is always considered a male job. Therefore, according to Mizejewski, [12] both in real life or as a cultural representation, the female detective is seen as transgressing male space, identity, and narrative (p. 7). The same idea has also been suggested by many scholars, in particular who used feminist perspective in their research. The similar finding of the scholars' research is that the cultural representation of female detectives always involves the question of how to represent the women as authorities who hold a gun, but still have popular appeal. Therefore, the cultural representation of the female detectives always requires certain textual strategies that are confined within the ideologies of femininity to solve the problems around issues of gender role and female sexuality. These strategies are needed to prevent cultural anxieties from emerging within American society, and this becomes a necessity to secure the popularity of the cultural texts. [11,12, 13, 14, 15, 16, 17, 18, 19]

The protagonist of The Closer solves every high profile crime case with the help of her mostly male detective subordinates, but her brilliance and competence in closing the case are conspicuous, and so is her leadership skill. For such a strong representation of a masculine female detective, creating feminine psychological vulnerabilities to counterbalance her masculinity and creating her to be a more integrated heroine by combining the masculine and feminine characteristics in her [16] (p. 101) become the natural textual strategies to deal with the problems around issues of gender role and female sexuality. Being represented as a female detective who is also a brilliant interrogator and an effective team leader, she needs to be created less masculine by making her stay feminine. This proves to be an effective strategy to create the female detective protagonist's stronger popular appeal that successfully becomes an important aspect of the series' long lasting popularity. [20]

Her femininity is made conspicuous from her look, demeanor, and utterance. Her dress style is conspicuously different from other female detectives on television. She rarely wears trouser and blazer combination that produces masculine look, instead she almost always wears a colorful blouse with ruffles underneath a blazer or cardigan matched with an A-line or half circle skirt or a one-piece dress in lightweight flowery or patterned fabrics underneath a blazer or cardigan. What makes her appearance more conspicuously feminine is that it is occasionally completed with a women' fedora hat and always with a big black purse and kitten-heels shoes. In fact, her big black purse becomes her signature style. It is more usual to find her without her gun and badge than without her big black purse. Her feminine appearance is accentuated by her unique style of giving instructions or getting her subordinates to do things by incorporating southern hospitality. The southern hospitality makes her directives and instructions softened and attenuated. Her use of the words please and thank you, according to Holmes, [21] shows a feminine style of doing leadership (p. 39) Since the normative style is the masculine style of leadership, the decision to represent a female detective protagonist as a woman leader with a feminine leadership style is able to produce a stronger popular appeal of the female detective protagonist.

The popular appeal is proven to be strong by the expanding of the demographic of the series' viewers to include female viewers as expected. Based on Kelly's observation, Kyra Sedgwick's fan site is clearly dominated by middle class women, Kelly suggests that the bond between the cast of The Closer's protagonist and her vast middle class female viewers centers less on her representation as a tough female detective and more on her representation as a common woman with common feminine psychological vulnerabilities. This can be seen from 
the hundreds of messages of these fans discussing Brenda Leigh Johnson's big black purse and love relationship with Fritz Howard (Jon Tenney). Kelly’s concludes that Kyra Sedgwick, like her character Brenda Leigh Johnson, has successfully gained trust of the female viewers who follow her fan site from the magic combination of masculine qualities and feminine psychological vulnerabilities. [22]

In other words, the police procedural drama series The Closer as a masculine cultural text has successfully transformed itself into a feminine cultural text by representing its female detective protagonist as a highly masculine protagonist who maintains her feminine sides in doing a male job. This well received transformation has expanded the viewers demographic to include female viewers who eventually give their feminine response. It turns out that the feminine response can be seen not only in Kyra Sedgwick fan site, but also in The Closer Fanfiction. The next part is the analysis of how the representation of the female detective protagonist of the American television police procedural drama series The Closer is read by The Closer's fanfiction writers in re-writing the female detective protagonist of the TV series as the original text. Do the writers take similar dominant-hegemonic reading position of the representation of The Closer's female detective protagonist with the series' female viewers?

\subsection{The Closer Fanfiction : The Celebration of Femininity}

This part of analysis used the data taken from the sources of data in the form of fiction works found in The Closer Fanfiction in the Archive of Our Own or AO3 site. The main reasons this site was chosen is because it is very active and has a huge library of fiction works and also because it has a very sophisticated search engine that makes it very easy to find certain fiction works. This sophisticated search engine is particularly useful for the data collection and selection process of this research. The search engine has made it very easy to pinpoint the exact type of fiction works needed as the data sources of the research and then to sort and filter the sources of data to meet the objective of the research, which is to find out what reading position is taken by The Closer's fanfiction writers in The Closer Fnfiction towards the representation of the female detective protagonist of The Closer (TNT, 2005-2012) in rewriting the female detective protagonist of TV series as the original text.

Thus, the sources of data were sorted and filtered by date posted from 2009 to 2016 to include The Closer's female detective protagonist Brenda Leigh Johnson and complete works only and exclude explicit content and crossovers. The sources of data must then include the fiction works that re-write Brenda Leigh Johnson as the female detective protagonist of the TV series. The posted date has reached the year 2020, but this research only focused on the fiction works posted from 2009 when the first works started to be posted in the AO3 site to 2016 so that the span of time is similar with the seven year span of time the series was on American television. Besides that, this research decided to exclude explicit content, but still include mature content for the reason to get fiction works that focused more on the character and characterization instead of the plot, which is basically referred to what the characters do. This research also decided to focus on The Closer TV series so that it excluded crossovers, which combine two or more fandoms in some way, for example The Closer and its spin-off Major Crimes or The Closer and other TV series. Last, but not least, the fiction works were all in English.

Among the ten ways to re-write a TV show proposed by Jenkins, [23] the writers of the fiction works in The Closer Fanfiction mostly chose to employ recontextualization, in which they wrote "short vignettes ("missing scenes") which filled in the gaps in the broadcast 
material and provided additional explanations for the character's conduct"; to expand the series timeline to fully explore "the hints or suggestions about the characters' backgrounds provided by the primary texts, but not fully explored within the episodes"; to employ emotional intensification, in which the writers as fans "relish[ed] episodes where relationships [were] examined, especially those where characters respond[ed] in a caring fashion to the psychological problems, professional turning points, personality conflicts, and physical hurts of other major characters"; and to utilize eroticization to create mostly "slash" fiction, especially Female/Female or F/F or "femslash", in which "the homosocial desires of series [female] characters erupt[ed] into homoerotic passion" (p. 180).

Some of the writers employed recontextualization in their early posted "slash" fiction works. They paired Brenda Leigh Johnson and Fritz Howard and Brenda Leigh Johnson and Andy Flynn. In the series, Brenda and Special Agent Fritz Howard were lovers who then became husband and wife, while Brenda and Lt Andy Flynn were foes to each other. In the early episodes, Lt. Flynn became Brenda's biggest adversary after Commander Russell Taylor who resented her for taking away his promotion to be the Head of Priority Homicide Division (PHD). Before Brenda saved his nearly ended career that made him request a permanent transfer to her team, Flynn often conspired with Taylor to sabotage Brenda's cases. Surprisingly, judging from the number of the fiction works, the from foe-to friend-relationship of Brenda and Andy is apparently more attractive to re-write than the love relationship of Brenda and Fritz.

The writers recontextualized an episode and at the same time they employed emotional intensification technique to represent the characters' response to the psychological problem of another character in the episode. Get Him Back written by mammothluv, [24] for example, recontextualized episode 3 of season 2 titled "Slippin", in which Brenda juggled responsibilities for entertaining her mother who came to visit from Atlanta and solving her murder case, and in the process she had Fritz to temporarily move out of her house because she was not ready to tell her mother that they had moved in together. The emotional intensification technique was used to represent Brenda's response to Fritz's upset and annoyed feeling to be forced to temporarily leave Brenda's house and put all of his stuffs in a rented UHaul. In Get Him Bad, Brenda is represented in the private, domestic sphere of her home and thus, it is her feminine qualities that are well explored. Two readers gave good responses. Each response shows that the writer has successfully met the readers' expectation of how the female protagonist should be represented in the fanfiction works.

jennylovescastle : Great story. I love it!! And totally in character. Thanks for writing :):):) [24]

LittleRiza ; That was great ! I totally see it happening on the show ! X) [24]

The phrase "in character" in the first response signifies that the representation of Brenda and Fritz in the fanfiction resembles their television representation. The second response basically underlines the fact by saying that the stories can be more than just a "missing scene". It has the quality to be picked up as an actual scene in the TV series.

Another example is part 1 of the Nemesis series titled Nemesis written by Abraxas, [24] which recontextualized episode 13 of season 5 titled "Elysian Field", in which an old police veteran Joe Olin became a vigilante to get the information of the graveyard of a murderer's victims, and the emotional intensification technique was used to represent Brenda's and Flynn's responses to Olin's act, acknowledging the urge to commit a vigilant act when they 
were forced to let go of the criminals and how they needed to constantly control the urge. In Nemesis, the emotional intensification technique allows the writer to deeply explore Brenda's emotional restless to be haunted by the criminals whom she failed to get confessions from. The exploration allows the writer to represent Brenda in her vulnerable state, in which she felt the strong urge to go into chocolate and sweets to reduce her stress. In the TV series, Brenda's sweet tooth problem has been used to counterbalance her masculine qualities. [2]

She needs the taste, the rush of sugar, the thing to take her to that other place where none of this exists; and her hand moves to open the drawer but then stops because she remembers the mixture of pleasure and pain she's keeping in there now and she can't see his face again, not now, not tonight. [24]

The emotional intensification technique works well in "femslash" fiction works. Brenda Leigh Johnson and Sharon Raydor were the most chosen and well received pair. In the series, Capt. Sharon Raydor also started with a hostile relationship with Brenda for doing her job as the Head of Force Investigation Division (FID) to investigate Brenda's conduct of unbecoming. The incidents that involved Raydor in Brenda's professional life were full of "moments of narrative crisis". Fans got lots of opportunities to relish episodes where Brenda's and Sharon's relationship was examined, especially those where Sharon responded in a caring fashion to Brenda's psychological problems, professional turning points, personality conflicts, and physical hurts. [23] This explains why the pairing is the most chosen and well received. Before joining Brenda's team permanently in season 7, Sharon became a recurring character in season 5 and 6 . Therefore, some of the fanfiction writers started to pick up her romantic and sexual relationship with Brenda in 2010. After that, almost all of the "slash" fiction works in The Closer Fanfiction were the "femslash" of Brenda and Sharon. Starting from 2012, there were seventeen to nineteen "femslash" of Brenda and Sharon in twenty fanfiction works. If Brenda and Sharon were heterosexual in the original text, they were represented as lesbians and/or bisexuals in the fanfiction works. When the represented relationship was sexual, the writer tends to employ eroticization technique.

In many of the "femslash" fiction works involving both romance and sex, Brenda and Sharon are represented in the private, domestic sphere of their home, and thus, it is their feminine qualities that are well explored. Some examples can be taken to support this argument. The Taste of Her Cherry Chapstick by sarken centers on Brenda's and Sharon's conversation about Brenda's flavored lip balm when spending time together. Toothbrush by sarken simply tells about Brenda confronting Sharon about borrowing her toothbrush when they spent time together. Stupid and Endless Nights by UbiquitousMixie focus on Brenda's inner thoughts and feelings about her relationship with Sharon. A Night Like This by surena_13; part 2 and 3 of the Reboot The Closer titled Balcony - Season 3 Ep 4 and Kitty by ultragirlvfr750; Chocolate Covered You (or, In Which Brenda and Sharon Have a Conversation) by cptraydorsgf; and And All Things Nice by parcequelle are among the many "femslash" fiction works that tell about Brenda and Sharon spending their night together in Sharon's house; watching TV and eating pizza, sipping a cup of coffee or beer or a glass merlot, cooking and having breakfast or dinner, or just talking before or after having sex. [24] The readers loved the exploration. In fact, it is the "femslash" that usually gets many comments. The following comment can well represent the readers' good responses. 
Phantomlistener : HI I'm in Brenda/Sharon hell and its all your fault! This is so goodddddd I love the domesticity and the tension and the flirting-disguised-asbanter...and basically everything about this [love eyes emoji] [24]

In the "femslash" fiction works taking the public sphere of the office, the plot or the sequence of events revolves around personal matters more than office matters. Some examples that can be taken to support this argument are Ding Dongs and Doors by surena_13, which ends with how Brenda's need to indulge herself in Ding Dong chocolate to release her stress after her interview for the LAPD Chief of Police was miraculously gone after she kissed Sharon; Like a Heartbeat Drives You Mad by missparker, which consists of 5 chapters narrating Brenda's and Sharon's undercover task as a couple that brings out the decaying marriage of Brenda and Fritz and the romantic attraction between Brenda and Sharon; 'Cause You Control the Floodgates by parcequelle, which picks up Brenda's and Sharon's hostile relationship by representing their banters and changes them into romantic hints of their attraction to each other; I Need Your Body From Dusk Until Dawn by sarken, which involves a stakeout and an accidental kiss; and etc. [24] Since personal matters become the focus, the overall tone of these "femslash" fiction works is often soft. It is often humorous too, but the soft tone is stronger that it creates the impression of reading feminine texts. One of the comments for 'Cause You Control the Floodgates represents the reader's good response of this mix of tone.

newgame : ... I think you captured Brenda and Sharon perfectly. I love the way you wrote their banters, I love their ridiculous plans, and I love that they're just helpless against the attraction they can't quite deny.... [24]

Two comments, one for chapter 2 and the other for chapter 4, of In Like a Heartbeat Drives You Mad highlight the joy of reading a feminine text. In chapter 2, the writer delivered her promise to write about clothes, about "WHAT ARE [THE CHARACTERS] GONNE WEAR?" [24] One of the comments she received shows that she delivered it successfully.

zoethart: This is getting very exciting! And I so love Brenda in protective mode but I'm very very worried about Sharon. Oh no! And I love how you dressed them! And the whole awkward scene in the bedroom: delicious! Thanks for the yummy juicy update. [My italics] [24]

For the other reader Dominicque, the joy of reading chapter 4 is the way the writer wrote the characterization.

Dominicque: I enjoyed that you kept them true to their character, all changes were smooth and credible, it's not a happy girly story, it's just life happening and that's what I loved about it.

Thanks for sharing your imagination. [24]

In Dominicque's opinion, although it's not a happy one, it is a girly story, and this opinion signifies the fact that this reader enjoyed reading a feminine text very much.

Either taking the private, domestic sphere or the public sphere, these "femslash" fiction works indeed celebrate femininity. It can be argued that most of the fanficion writers in The Closer Fanfiction are women because in all of the slash fiction, particularly the "femslash", 
the writers' use of the third person point of view allows them to delve into their characters' mind and feeling in representing their characters and to emphasize on the need to obtain tenderness, slow process, and exclusive commitment in representing the characters' relationship. This argument is well supported by Handley and Jenkins, who suggest that the majority of the writers of fanfiction, especially "slash" fiction are women so that "slash" fiction is an exclusively feminine genre. [8, 23] Jenkins further highlights Joanna Rush's findings on female writers' style of writing the Male/Male fiction that basically represents "a projection of female sexual fantasies, desires, and experiences onto the male bodies of the series characters". [my italics] [23] Analyzing the "femslash" fiction works in The Closer Fanfiction, it can be argued that the female writers of the Female/Female or F/F or "femslash" fiction also use the same style of writing that represents the projection of female sexual fantasies, desires, and experiences onto the female bodies of the series characters.

Femininity is also celebrated through exploring not only the feminine sides, but also the feminine vulnerabilities of the female detective protagonist in the fiction works and the readers' comments show that the representation fits their expectation. That Pink Cardigan Must Go by ultragirlvfr750 is a perfect example. The writer's summary shows that she also employed recontextualization.

Set firmly in the Closer Universe. Season 5 - ep 15 - the iconic scene where Brenda and Sharon finally admit to the fact that they don't like one another. Except I call bullshit because there was enough unresolved sexual tension in that scene to ruin a thousand pairs of panties. This fic takes place directly after Sharon awkwardly walks out of Brenda's office and is my imagining of what happened next. [24]

The writer picked up Brenda's feminine appearance and her sweet tooth problem in the series in re-writing the character and her characterization.

And why was she still sitting in her office, apparently mesmerized by the way the younger woman tossed her blonde ponytail or brought her hand up to scrub at her furrowed brow? Why, the longer they investigated the case of Ally Moore, had she made up reasons to stand close to the Chief just to catch a whiff of her perfume? Something flowery, like the hideous skirts she insisted on wearing.

And speaking of hideous, someone should really tell Brenda that there was everything wrong with a pink double-knit cardigan. Except she couldn't seem to tear her eyes away from the front of it. She coughed and shook her head.

She should be packing up. Heading home. Getting back to worrying about why Fritz seemed so angry and distant these days.

Instead she pulled open her candy drawer, yanked out a twizzler and jammed it in her mouth. The sugar hit her system immediately, momentarily drawing her attention away from the aching between her legs.

She splayed back in her chair, pushing the liquorice slowly back and forth in her mouth, feeling it slide against her lips, tasting the sweetness and wondering absently 
what it would be like to kiss Sharon Raydor. What it would be like to taste her. Would she be sweet? [my italics][24]

Another good example is Kitty by ultragirlvfr750. Kitty was written as "a part of [the writer's] Reboot the Closer series" that employed recontextualization of "the deleted scene from Season 1 - episode 3 - The Big Picture". This "femslash" particularly explores Brenda's feminine vulnerability.

She'd just wanted the damn cat to stop crying.

She'd just wanted to stop missing Atlanta and her mother's home cooking.

She'd just wanted to stop pretending for a moment that she was fine with the fact that she was hated by everyone she worked with.

If she were honest what she'd really wanted was to simply bury her head in Sharon Raydor's chest and have herself a damn good cry.

If in That Pink Cardigan Must Go one of the comments focused more on the writer's use of the recontextualization and eroticization techniques, in Kitty, one of the comments specifically addressed the writer's exploration of the female detective protagonist's feminine vulnerability and it signifies that the exploration fits her expectation.

Amanda : I absolutely LOVE this series, and this new addition is no exception <3 $<3<3$ Absolutely perfect characterization, storyline, and descriptions. Just completely all around perfection $<3<3<3<3$ [24]

The "perfect characterization" for both Brenda and Sharon, particularly in the "femslash" fiction works, signifies the way the television representations of Brenda and Sharon were read by the fanfiction writers. In the "femslash", Sharon is represented with a more masculine characterization, while Brenda is with a more feminine characterization. This is more clearly perceived in some examples in which Sharon is represented as Brenda's "saviour". In Death Wish by UbiquitousMixie, it was Sharon who saved Brenda by shooting the criminal who pointed a gun to Brenda in her house and became the female hero.

It's Raydor who takes the final shot, in the end-Raydor who saves the day, who shakes Brenda's shoulders so hard that the deputy chief has to blink and remember that she's still alive. Brown eyes focus hazily on Sharon's service weapon and then on the body, observing the tableau as if she's not a part of it. It's not until the acrid scent of gunpowder fills her nostrils that she's there, grounded in the startling reality of it all. The bile rises in her throat and tears sting her eyes, and she allows Sharon to pull her tightly into her arms in front of her team, her husband. [my italics][24]

In Undone by Averita, Brenda was a mess after the loss of her mother, husband, and team and Sharon provided a shoulder to cry on. 
"It's okay," [Sharon] says, trying to sound reassuring. "I understand. Everything's falling apart, I know it is - your mother, your husband, even your team." Brenda flinches as though she's been slapped, but Sharon continues as gently as she can, speaking around the lump in her own throat. "And I'm here, and I'm convenient. And that's okay," she insists before Brenda can interrupt, "it really is. But - let's not make it more than that." [24]

In Dead Men Die, a Zombie Alternate Universe (AU), by surena_13, Sharon saved Brenda and her team from Zombies and became the female hero.

"I know that in the academy they teach to aim for the centre mass, but with these things, you really should aim for the head," Sharon said calmly before she shot another bullet into one of the creatures' skulls. She holstered one gun, but kept the other in her hand.

"And who made you the lead expert on zombies?" Provenza sneered. Brenda wanted to hit him on the back of the head. The woman had just gotten rid of all of the creatures that had threatened them and he was trying to piss her off. Sharon narrowed her eyes and looked ready verbally tear Lieutenant Provenza to pieces and rightfully so when something cold wrapped itself around Brenda's ankle and she let out an undignified yelp.

$\ldots$... [my italics][24]

The readers' good responses signify that the contrast characterization of the two characters have met their expectation. KittyKait gave her comment in Undone and little_ruby gave hers in Dead Men Die.

KittyKait: Thus almost had me in tears. My little shipper heart aches for Sharon in this story 1 . So so sad. But also so fabulously in character and real. I loved it.

My only question now is why have you only written two The Closet stories? You are so flipping good at it!!! [my italics][24]

little_ruby : this is just perfect. and just the way it would go with these characters. at least in my opinion. and I really hope you get some cheap merlot anytime soon. because this needs more chapters. waaaaaaaay more chapters XD [my italics][24]

Both readers highlighted their love of how the writers developed the characters and their characterization. "In character and real" in the first comment signifies that in the reader's opinion, the way the characters and their characterization is represented in the "femslash" matches with their television representation.

It has been mentioned in the previous part of this discussion that in the TV series, although Brenda is conspicuously represented as a brilliant interrogator and an effective team leader, her feminine look, demeanor, and utterance are as conspicuous so that she is seen as an integrated heroine. Upon a closer analysis of the combination of the development of the characters, the narration of the sequence of events, and the juxtaposition of the scenes in the 
TV series, however, the female detective protagonist's feminine sides and vulnerabilities are represented to counterbalance her masculine qualities so that her feminine image stays strong. [2] This can explain why Brenda's image tends to be more feminine than Sharon's, and apparently it was the image that was read from the representations of Brenda and Sharon by the fanfiction writers in re-writing the characters and their characterizations and by their readers who claimed to love the in characters and their true characterizations.

In other words, the fanfiction writers and the readers of their fiction works also took the similar dominant-hegemonic reading position of the representation of The Closer's female detective protagonist with the other female viewers of the series. They have taken the message in the exact way the producer of The Closer TV series sent it. It means that because they, as consumers, accepted the intended meaning, the fanfiction writers and their readers shared the same ideological background, which basically was the ideologies of femininity, [14] with the producer. This signifies that the fanfiction writers and their readers comply with the idea that what is accepted as normal for women is to stay feminine even when they are able to perform great masculine qualities. The compliance proves that the producer of The Closer TV series has successfully used its institutional power to articulate and reinforce the continuation of discursive formations about female detective, television police procedural drama series, and female leadership by making its female detective protagonist a spectacle. [2] Together with the other female fans of the TV series, the fanfiction writers and their readers have taken "the pleasures of self-recognition, of finding women placed center-staged in '[masculine genre]', of participation in a shared "women's culture", , but have been unaware of being "contained within the accepted bounds of femininity" [14] (p. 7) in their viewing, writing, and reading activities.

\section{Conclusion}

In conclusion, the fanfiction writers and their readers in The Closer Fanfiction in the Archive of Our Own (AO3) site took the similar dominant reading position of the representation of the female detective protagonist of The Closer TV series with the other female viewers of the series. It is shown from the maintaining of the female detective protagonist's basic characterization in the re-writing of the character in the fanfiction works. As a result, the female detective protagonist's feminine sides and vulnerabilities were explored more in her representation in the fanfiction works, particularly the Female/Female or F/F or "Femslash" fiction works.Taking the dominant reading position means that together with the other fans, the fanfiction writers and their readers share the same ideologies of femininity with the producer of The Closer TV series in taking the pleasures of recognizing themselves and their own life experience, of watching a badass, but still a woman placed center-staged in a masculine television police procedural drama series, and of participating in a shared "women's culture" while viewing, writing, and reading the representation of the female detective protagonist of The Closer TV series on TV and in the fanfiction works. However unaware these fans of having complied with what is accepted as normal for women in American society, in which the masculine is the norm, in this way the ideologies of femininity is continuously maintained in the life experience of American women. 


\section{References}

[1] Rowe JC. A concise companion to American Studies. West Sussex: Blackwell Publishing Ltd.; 2010. Introduction: p. 1-16.

[2] Primasita FA. Representation of female detective in American police procedural drama series The Closer (TNT, 2005-2012) [Unpublished Digital Dissertation]. Yogyakarta: Gadjah Mada University; 2019 [cited 2020 August 28] Available from: http://digilib.fib.ugm.ac.id/digital/filter

[3] Opperman M. The World Wide Web and digital culture: New borders, new media, new American Studies. In: Rowe JC. (ed.) A concise companion to American Studies. West Sussex: Blackwell Publishing Ltd.; 2010. p. 334-349.

[4] Rowe, JC. Next Times: The futures of American Studies today. American Literary History. 2013;25(1): 257-270.

[5] Lister M, Dovey J, Giddings S, Grant I, Kelly K. New media and new technologies. In: Lister M, Dovey J, Giddings S, Grant I, Kelly K. New Media: a critical introduction (2 ${ }^{\text {nd }}$ ed.) Oxon : Routledge; 2009. p. 26-121.

[6] Breer D. Popular culture and new media: The politics of circulation. London: Palgrave Macmillan; 2013. Introduction: p. 1-21.

[7] Lotz AD. What is U.S. television now? The Annals of the American Academy of Political and Social Science, 2009;625: 49-59.

[8] Handley C. Narrative critique and reinterpretation in Star Wars Fanfiction. In: Larsen K and Zubernis L. (eds.) Fan Culture: Theory/Practice. Cambridge: Cambridge Scholars Publishing; 2012. p. 97-118.

[9] Van Dover JK. Preface. In: Van Dover JK. We must have certainty: Four essays on the detective story. Selinsgrove, PA: Susquehanna Univ. Press; 2005. p. 9-15

[10] Cooper S. Sex/knowledge/power in the detective genre. Film Quarterly, 1989;42(3): 2331. Availabe from: doi:10.1525/fq.1989.42.3.04a00040.

[11] Mizejewski L. Watching the women detective. In: Mizejewski L. Hardboiled and high heeled: The woman detective in popular culture. New York: Routledge; 2004. p. 1-17.

[12] Mizejewski, L. Picturing the female dick: The Silence of the Lambs and Blue Steel. Journal of Film and Video, 1993;45(2/3): 6-23.

[13] Mizejewski, L. Dressed to kill: Postfeminist noir. Cinema Journal, 2005;44(2): 121-127. Available from: doi:10.1353/cj.2005.0010.

[14] Thornham S. Introduction: thinking women/media/feminism. In: Thornham S. Women, feminism, and media. Edinburgh: Edinburgh University Press; 2007. p. 1-22.

[15] Finley-Croswhite A. Steele mad after all these years: "Remington Steele's" Laura Holt and women's rage on 1980's Television. Studies in Popular Culture, 1996:19(1): 19-36.

[16] Dole CM (2001). The gun and the badge: Hollywood and the female lawman. In: McCaughey M and King N (eds.). Reel knockouts: Violent women in the movies. Austin: University of Texas Press; 2001. p. 78-105.

[17] Tasker Y. Investigating women: Work, criminality and sexuality. In: Tasker Y. Working girls: Gender and sexuality in popular cinema. London: Routledge; 2003. p. 91-113.

[18] Lavigne C. Death wore black chiffon: Sex and gender in CSI. Canadian Review of American Studies, 2009:39(4): 383-398. Available from: doi:10.1353/crv.0.0047.

[19] Brown JA. Dangerous curves: Action heroines, gender, fetishism, and popular culture. Jackson, Mississippi: The University Press of Mississippi; 2011.

[20] Duff J, Shephard G, Robin MM, Wallace R, Sedgwick K. Confessions of the closer [DVD special feature]. America: Warner Bros; 2009. 1 DVD: sound, colour. 
[21] Holmes J. Gender and leadership talk at work. In: Holmes J. Gendered talk at work constructing social identity through workplace interaction. Malden: Blackwell Publising; 2006. p. 32-73.

[22] Kelly J. The Closer: The complete third season. PopMatters [Internet]. 15 July 2008 (cited $20159 \mathrm{March}$ ). Available from: www.popmatters.com/the-closer-the-completethird-season-2496138008.html.

[23] Jenkins H. Scribbling in the margins: Fan readers/fan writers. In: Jenkins H. Textual Poachers: Television fans \& participatory culture. Taylor \& Francis e-Library; 2005. p. 155-254.

[24] The Closer Fanfiction. The Archieve of Our Own [Internet]. Ruby: Organization for Transformative Works; 2008 [launched 2009 November 15, cited 2020 August]. Available from : https://archiveofourown.org/tags/The\%20Closer/works. 